AperTO - Archivio Istituzionale Open Access dell'Università di Torino

\title{
CONNECTIONS BETWEEN GUT MICROBIOTA AND BONE HEALTH
}

\section{This is a pre print version of the following article:}

Original Citation:

\section{Availability:}

This version is available http://hdl.handle.net/2318/1686080

since 2019-01-08T12:41:18Z

Publisher:

Faintuch J\&Faintuch S

Terms of use:

Open Access

Anyone can freely access the full text of works made available as "Open Access". Works made available under a Creative Commons license can be used according to the terms and conditions of said license. Use of all other works requires consent of the right holder (author or publisher) if not exempted from copyright protection by the applicable law. 


\section{(2) \\ UNIVERSITÀ DEGLI STUDI DI TORINO}

This is an author version of the contribution published on:

Questa è la versione dell'autore dell'opera: CONNECTIONS BETWEEN GUT MICROBIOTA AND BONE HEALTH.

D'Amelio $P$, Sassi $F$.

Within the book

book Microbiome and Metabolome in Diagnosis, Therapy, and other Strategic Applications (ISBN: 9780128152492).. 
"CONNECTIONS BETWEEN GUT MICROBIOTA AND BONE HEALTH"

$\mathrm{D}^{\prime}$ Amelio $\mathrm{P}^{1^{*}}$ (Senior Author), Sassi $\mathrm{F}^{1}$ (Postdoctoral Fellow)

${ }^{1}$ Department of Medical Science, Gerontology and Bone Metabolic Disease Section, University of Torino, Torino, Italy

*Corresponding author: patrizia.damelio@unito.it

RUNNING TITLE: bugs and bone 


\section{ABSTRACT}

The gut microbiota (GM)-host interactions contribute to the maturation of the host immune system, and modulates its systemic response. It is well documented that GM can interact with non-enteral cells such as immune cells, dendritic cells, and hepatocytes, producing molecules such as shortchain fatty acids, indole derivatives, polyamines, and secondary bile acid. The receptors for some of these molecules are expressed on immune cells, and modulate the differentiation of $\mathrm{T}$ effector and regulatory cells: this is the reason why dysbiosis is correlated with several autoimmune, metabolic, and neurodegenerative diseases. Due to the close interplay between immune and bone cells, GM has a central role in maintaining bone health and influences bone turnover and density. GM can improve bone health also increasing calcium absorption and modulating the production of gut serotonin, a molecule that interacts with bone cells and has been suggested to act as a bone mass regulator. Thus, GM manipulation by consumption of antibiotics, changes in dietary habits, and the use of pre- and probiotics may affect bone health.

\section{KEY WORDS}

Gut microbiota, Bone, Osteoporosis, Immune system, Probiotics, Inflammation.

\section{CONTEXT}

In physiological condition, GM relationship with host is complex and comprehends various forms of symbiotic relationship such as parasitic, commensal, and mutualistic. GM helps in food digestion, in fighting pathogens and, during the first years of post-natal life, contributes to the maturation of the host immune system. During the whole life, GM interacts with the host and contributes to the modulation of gut and systemic immunity. Immune homeostasis disruption is the causal mechanism of several chronic non-communicable human diseases (NCDs) such as allergy, asthma, some autoimmune, cardiovascular and metabolic diseases, and neurodegenerative disorders. These disorders are characterized by a low grade of inflammation. Although inflammation and the pathways to disease are multifactorial, the altered gut colonization patterns, associated with decreasing microbial diversity, are a central theme and are increasingly implicated 
in the physiologic, immunologic, and metabolic deregulation seen in many NCDs. Altered GM-host interaction has been indicated as a possible cause of immune deregulation and increased inflammation associated with several NCDs $(1,2)$.

\section{MOLECULES AND PATHWAYS}

Products of microbial metabolism signal to the host and influence his/her metabolism, GM metabolize some products that are introduced with diet and are not absorbable by the host, these substrates (most commonly complex carbohydrates) are able to influence GM and GM-host interaction and are known as prebiotics. Prebiotics cannot be digested by human enzymes and are fermented in the colon by GM to yield energy for microbial growth and end products such as shortchain fatty acids (SCFAs), mainly acetate, propionate and butyrate.

Butyrate is particularly important as an energy substrate for cellular metabolism in the colonic epithelium, whereas acetate and propionate are taken up by the liver and used as substrates for lipogenesis and gluconeogenesis. SCFAs also affect proliferation, differentiation and modulation of gene expression in mammalian colonic epithelial cells $(3,4)$. However, these effects have been attributed to butyrate acting as a potent histone deacetylase inhibitor and, as such, it may regulate the mammalian transcriptome.

It has been demonstrated that SCFAs have anti-inflammatory effects on intestinal mucosa, thus protecting the bowel from the development of inflammatory bowel disease (5-7). SCFAs signal to several non-enteral cell types through G-protein-coupled receptors and the signal between GM and immune system is fundamental to regulate the homeostasis and to maintain the balance between immune tolerance to commensals bacteria and immunity to pathogens.

It has also been suggested that, depending on the cytokines milieu, interaction between SCFAs and their receptors influences $\mathrm{T}$ cells differentiation not only toward $\mathrm{T}$ regulatory cells (Tregs), but also toward effector $\mathrm{T}$ cells. Furthermore, butyrate and propionate also modulate antigens presentation inhibiting the development of dendritic cells by gene expression regulation (8-11) and by interaction with SCFAs receptors $(12,13)$ 
Beyond SCFAs, GM produces other metabolites, such as indole derivatives and polyamines, from digested food that have important immunomodulatory function. These metabolites derive from dietary tryptophan and arginine, respectively, and have an indirect immune function. Indole derivatives favor the integrity of the enteral mucosa and the barrier defense toward pathogens by stimulating the production of anti-microbial peptides, mucins, and proliferation of intestinal goblet cells. Polyamines such as putrescine, spermidine, and spermine fulfill important roles in gene expression and proliferation. They enhance the development and maintenance of the intestinal mucosa and resident immune cells (2).

The primary bile acids are synthesized in the human liver from cholesterol, and are important for ensuring that cholesterol, dietary fats and fat-soluble vitamins from the small intestine are soluble and absorbable. Primary bile acids are conjugated to glycine in humans, and are taken up in the distal ileum for transport to the liver. However, bacteria in this part of the ileum deconjugate these bile acids, which then escape intestinal uptake and can be further metabolized by the GM into secondary bile acids. Bile acids are taken up from the gut and circulate throughout the body, acting as signaling molecules and binding to cellular receptors in peripheral organs, where may contribute to overall host metabolism. An immunomodulating role has also been postulated for metabolized bile acids; however, physiological role of these metabolites in health and disease is still an open question (14).

Polysaccharide $\mathrm{A}$ is a bacterial product that influences $\mathrm{T}$ cells fate through its interaction with the toll-like receptor 2. Interacting with $\mathrm{T}$ cells, it favors immune tolerance by inhibiting $\mathrm{T}$ helper 17 differentiation and favoring Tregs activity (15).

In summary, GM influences T cells differentiation through the production of bacterial metabolites at least at the intestinal mucosa level and $\mathrm{T}$ cells differentiation through cognate bacterial antigens (16). The molecular pathways are summarized in Figure 1.

\section{IN VITRO AND IN VIVO MODELS}


Use of model systems with different levels of microbial complexity reveals how host genes impact the microbiome and how the microbiome regulates host genetic programs. Model organisms provide opportunities to study host-microbiome interplay with a level of experimental control that is not achievable in human studies (17). Model systems are also revealing roles for the microbiome in host physiology ranging from mate selection (18) to skeletal biology $(19,20)$ and lipid metabolism $(21,22)$.

With an ever-increasing number of human microbiome studies completed and under way, experimental systems employing models organisms will prove essential tools to interrogate and validate the associations identified between the human microbiome and disease $(23,24)$.

Germ-free (GF) animals are reared in sterile isolators to control their exposure to microorganisms, including viruses, bacteria and eukaryotic parasites (24). If these animals are colonized with microbial communities of specific donors (human or other animal species) they become gnotobiotic and therefore allow analysis of the systemic impact of specific microorganisms on the xenograft recipient (25).

Being able to associate a specific function to a particular bacterial strain or species is of great importance considering the possibility that specific organisms could be used as a treatment for a given disease.

Therefore, the beneficial impacts of a single bacterial species/strain on the host should be validated by taking into account the full microbial community context. Nevertheless, GF animals show a number of important physiological differences when compared to conventionally raised animals, for this reason data extrapolated from experiments carried out with GF animal models must be considered with caution.

Although different animal models (zebrafish, mice, rats and pigs) have been developed, mice represent the most widely used and best characterized model organisms: infact, 99\% 
of mouse genes are shared with humans at the host genetic level, and they share key similarities with the human gut microbiome, making them a powerful model system for evaluating hostmicrobiota interactions applicable to human biology $(17,26)$.

Mouse genetics, the availability of strains and collections of knockout, knock-in and transgenic mutants, make mice a useful model system for studying the role of host genetics in host-microbiota interactions. However, in some cases, confounding factors have made drawing conclusions from the impact of mouse genetics on the microbiome far from clear: the point is to highlight that studying host-microbiota interactions in mice requires careful experimental design (17).

Furthermore, they often do not yield reliable preclinical results that readily translate into effective human treatments. Two important factors contribute to this failure: bacterial species that colonize the gastrointestinal tract appear to be host-dependent, so a specific microbiota is critical for a given host (27); and the immune responses in non-human mammalian species is often distinct from those seen in human $(28,29)$

\section{GM, IMMUNE SYSTEM AND BONE LOSS}

The interaction between immune system and GM has a central role in the maturation of immune system during the early post-natal period $(2,30)$ and a role in the modulation of immune system and response to self-antigens during the whole life $(30,31)$; thus it has been suggested that dysbiosis may play a role in the development of diseases characterized by immune deregulation such as allergies, autoimmune, and inflammatory disorders.

The role of GM in the development and maturation of host immune system in the early post-natal life has been demonstrated in GF mice: the use of this experimental model has shown that the absence of GM negatively influences the formation of lymphoid organs; in particular, GF mice have defective formation of the spleen and mesenteric lymph nodes, the intestinal Peyer's patches are smaller, and display a reduced number of CD4+ T cells and reduced production of $\operatorname{IgA}(23,32-36)$. Also isolated lymphoid follicle and cryptopatches are reduced in GF mice $(37,38)$. 
As regards, immune cells of different GM phyla were associated with the development of different T helper (Th) phenotypes: infact, GF mice have imbalance in T helper cells, reduced Treg, absence of Th17 cells, and altered ratio between Th1 and Th2 with increased Th2 response (39).

Arthritic phenotypes are restored when GF animals are colonized with segmented filamentous bacteria, which enhance the differentiation and function of Th17 cells; also colonization of GF animals with Bacteroides fragilis restores a correct balance between Th1 and Th2 cells and redirects lymphoid organogenesis (35). Resident bacteria, such as segmented filamentous bacteria and in particular some Clostridia-related species, have been associated to Th cells development and to Tregs cells induction $(40,41)$.

The majority of the evidences thus suggest that GM metabolites and antigens may influence immune regulation and hence dysbiosis may be the environmental factor responsible for some immune and inflammatory disorders, both at gut level such as inflammatory bowel disease (42) and outside the gut such as Rheumatoid Arthritis (43), type 1 diabetes (44), and asthma (45). However organs distant from gut, skin, and lung are not in direct contact with GM. This implies that GM has the ability to communicate with the host immune system in distant organs as well as in the gut. These signals have been identified in GM-derived products and also in circulating antibodies or immune cells (46).

Osteoporosis increases dramatically the risk of fractures: major osteoporotic fractures are a social and economic burden. In developed countries, the lifetime risk for osteoporotic fractures at the wrist, hip, or spine is $30-40 \%$, very close to that for coronary heart disease. The number of new fractures in 2010 in the EU was estimated at 3,5 million, comprising approximately 620,000 hip fractures; 520,000 vertebral fractures; 560,000 forearm fractures; and 1,800,000 other fractures (47). Osteoporotic fractures impair patients' quality of life and increase mortality: $20 \%$ of elderly patients suffering from femoral fractures will die within a year, and $50 \%$ of the survivors will lose independence. The most frequent cause of bone loss is postmenopausal osteoporosis (PMO) that is driven by estrogen deficiency at menopause. In PMO, there is an imbalance in bone turnover with 
increased bone resorption and reduced bone formation. It has been demonstrated both in experimental models and in humans that estrogen deficiency affects bone cells number and activation and bone turnover partially through its effect on immune system (48). During estrogen deficiency, $\mathrm{T}$ cells increase their production of pro-inflammatory and pro-osteoclastogenic cytokines, such as TNF alpha and RANKL (49); however, the reasons of this increased activity in osteoporotic women and not in non-osteoporotic subject are unknown.

GM may be involved in the mechanism of PMO. It has been suggested that the absence of GM influences bone mass: the majority of the findings demonstrate that GF mice have increased bone mass and report an acute effect of GF colonization with GM obtained from conventionally raised mice on reduction of bone mass due to increased bone resorption, whereas the long-term colonization resulted in a net skeletal growth in young animals (50). Studies on mice treated with broad spectrum antibiotics to alter GM bring to different conclusions regarding the effect on bone density. These discrepancies are possibly due to differences in animal age, sex, and protocols applied for antibiotic treatment (19,50-53). However, the majority of the reports suggest that antibiotic-treated mice have increased bone density $(19,53,54)$ and also best bone mechanical properties (54) than conventionally raised mice.

It is possible to induce a pharmacologically bone loss condition in mice with the GnRH agonists leuprolide and to investigate the role of GM in bone loss induced by sex steroid deficiency (55). These studies demonstrated that GM plays an important role in sex steroid deficiency-induced osteoporosis: GF mice are protected against osteoporosis and the increase in bone turnover induced by sex steroid deprivation thanks to the lack of increase in TNF, RANKL, and IL-17. Furthermore, sex steroid depletion augments inflammation in the intestine by increasing gut permeability to bacterial antigens, namely, by decreasing the expression of modulators of intestinal barrier integrity $(56,57,58)$.

In humans, scarce data support results obtained in mice.

Relationship between GM, immune system and bone in PMO are summarized in Figure 2. 


\section{GM AND BONE HEALTH BEYOND IMMUNE SYSTEM}

It has been suggested that GM composition and manipulation may affect bone health beyond immune system by influencing calcium absorption and the production of gut derived serotonin.

A post hoc analyses on the use of Lactobacillus reuteri demonstrated that the use of this probiotic in healthy subject increases the level of serum $25 \mathrm{OH}$ vitamin D that influences calcium absorption and benefits bone health. The mechanism through which this probiotic influences vitamin D level is not clear; however, this may be due to a modification in the gut environment that specifically favors vitamin D absorption or to indirect effect on increased hepatic 25-hydroxylase activity or 7 dehydrocholesterol concentration due to reduced absorption of dietary and biliary cholesterol $(2,59)$. On the other hand, the relation between GM and vitamin D may also be inverse as it has been proposed that decreased vitamin D intake is associated with different GM profiles $(60,61)$. Another possible mechanism through which GM benefits bone health is the increase in calcium absorption. It is well known that maintaining a positive calcium balance is important in achieving a good peak of bone mass that protects from the development of osteoporosis in older age $(62,63)$. Dietary intake of fibers influences calcium absorption: after being fermented by GM, fibers improve calcium absorption by reduction of gut $\mathrm{pH}$, thus reducing the formation of calcium phosphates and increasing the calcium absorption and by increasing the production of SCFAs such as butyrate (64). The effect of SCFAs may be more complex than the effect on gut $\mathrm{pH}$, and in fact it has been demonstrated that SCFAs increase calcium transport through signaling pathway modulation (65). As previously said SCFAs influence bone health also through immune system modulation; hence dietary fiber intake may be responsible for a healthier immune system and reduced inflammation. In fact, there is a general consensus recognizing that an adequate dietary fiber intake is associated with lower risk of chronic diseases such as cardiovascular disease (66). Another possible mechanism through which GM influences bone health is mediated by its effect on the production of gut serotonin (5HT). In recent past, a dual effect of serotonin in the regulation of bone mass has been described depending on the site of production of this molecule (67): a role as a bone mass regulator 
was proposed to gut-derived 5HT (g5HT), which is influenced by GM. Enterochromaffin cells of the duodenum are responsible for the synthesis of g5HT that is partially modulated by GM as SCFAs increase the synthesis of g5HT $(68,69)$. It has been shown that 5HT interacts with bone cells and, in particular, decreases osteoblast proliferation; these observations suggest that regulation of g5HT by GM may be a potential therapeutic strategy to improve bone health.

Indeed, in animal models of ovariectomy-induced bone loss, pharmacological inhibition of g5HT synthesis results in the prevention of osteoporosis mediated by increased bone formation (70). However, data on the effect of 5HT on bone health are quite controversial.

Relationship between GM, and bone beyond immune system are summarized in Figure 3.

\section{GM MANIPULATION AND BONE HEALTH}

GM composition may be manipulated in several ways such as the use of broad spectrum antibiotics, change in dietary habits and, more easily, by the use of prebiotics and probiotics, change in GM composition may affect bone health.

Prebiotics have been defined as "non-digestible food ingredients that benefit the host by selectively stimulating the growth or activity of one or a limited number of bacteria in the colon" (71). Prebiotics are complex carbohydrates and fibers that influence composition and/or activity of GM in a way that favors host health.

To be classified as a prebiotic, a substance should meet these criteria: be resistant to low gastric $\mathrm{pH}$, hydrolyzed by mammalian digestive enzymes, and not be absorbable by humans, be fermented by GM, and stimulate the growth and activity of gastro intestinal tract (72).

Dietary carbohydrates including resistant starches, non-starch polysaccharides and oligosaccharides can reach the large intestine directly by escaping the digestion of host enzymes and act as the major substrates for the growth of gut bacteria with specific carbohydrate enzymes $(73,74)$. Fructooligosaccharides (FOS) and galactooligosaccharides (GOS) are two well-known dietary prebiotics, which are widely used for improving metabolic disorders $(75,76)$. Moreover, improvement of gut barrier function also contributed to the beneficial effects of FOS (77). 
Prebiotic supplementation in animal models favors the proliferation of Bifidobacteria and increases SCFAs production. As regards the effect of prebiotics on bone health, some experimental studies showed that they improved calcium absorption and bone density in animal models $(78,79)$. In humans, the supplementation with different prebiotics in adolescent girls improved calcium absorption and bone density (80,81). Recently, the corn derived non-digestible carbohydrate, soluble corn fiber (SCF), has been evaluated for its ability to increase calcium absorption and improve bone health in humans. In particular, SCF administration enhances calcium absorption and its consumption is associated with a favorable change in GM, namely, increased presence of Bacteroidetes and Firmicutes known to ferment starch and fiber $(82,83)$.

Firmicutes are positively correlated with calcium absorption, suggesting that the role of GM in calcium absorption is complex due to different species (82).

Prebiotic fiber may influence bone metabolism both by the change in the composition of GMfavoring microbes with higher anti-inflammatory potential and by increasing SCFAs production thus increasing calcium absorption. It has also been suggested that prebiotics could have direct effect on immune system modulation and an anti-pathogen effect regardless to their effect on GM (84). However, until now, in human studies on prebiotics only calcium absorption, markers of bone metabolism, and bone density have been investigated, whereas immune phenotype and inflammation have not been investigated, Table 1 summarizes the results obtained in humans with different prebiotics.

As more and more beneficial intestinal bacteria are being found with the application of advanced sequencing techniques, the definition of prebiotics should be more specific, for instance, which phyla are promoted by the probioticts and possible clinical application, in the near future new prebiotics are expected to be developed (73).

GM may be manipulated also by the administration of probiotics. 
According to the definition from the Food and Agriculture Organization of the United Nations and the World Health Organization, probiotics are "live microorganisms which provide a health benefit on the host when administered in adequate amounts" $(73,85)$

The majority of experimental data produced in mice demonstrated that modulation of GM by the use of probiotics is able to increase bone mass and reduce sex steroid associated bone loss $(55,86-$ 88). Probiotics used were different in different studies, both a single strain or a mixture of strains. The most used were Lactobacilli spp. that were demonstrated to have the higher anti-inflammatory and bone protective effect. Also some data on the use of yogurt that contains different probiotics, but is also a source of calcium and proteins that are fundamental for bone health, have been produced (89). All these studies showed a protective effect of probiotic yogurt on bone health. Moreover, it has been demonstrated that dairy products consumption in early life led to a higher peak bone mass (90). Also in adults older than 60 years, consumption of dairy products was associated to increased bone density and lower risk of osteoporosis (91-94). The use of probiotics has been proposed also as an adjuvant treatment in focal bone loss such as alveolar erosion in periodontitis. The ability of different Lactobacilli strains in reducing osteoclast number, alveolar erosions, and tooth movement in rat and mice has been demonstrated (95-97). In humans, a recent meta-analysis concludes that current evidences suggest a possible use of probiotics as an adjuvant therapy in gingivitis and periodontitis (98). In a geriatric population, the administration of Lactobacillus helveticus increases serum calcium (99). Also in osteopenic women, the administration of a multispecies probiotic (6 different species) increases markers of bone formation, decreases TNF alpha level, but has no effect on bone density during a 6-month period (100).

With the development of high-throughput sequencing, more and more bacteria with probiotic activity will be found, but how to obtain specific conditions to culture them is still a big challenge. However, it is still not clear whether these novel probiotics are absolutely safe to human health. Thus, future works focusing on the understanding of the microbe-host relationships are warranted. 
Gnotobiotic animals are valuable tools used to evaluate the physiological functions of each probiotic strain (73).

Also the use of antibiotics is known to have significant effects on the intestinal microbiota.

The use of high-throughput metabolomics has shed light on the interactions between the intestinal microbiota, the host and the use of drugs, showing that antibiotic treatment disrupts intestinal homeostasis and has a profound impact on the intestinal metabolome.

A single, high dose of the antibiotic streptomycin can have a profound impact on many crucial host metabolic functions: among some of the pathways affected are those involved in sugar, amino acid, fatty acid, bile acid, steroid, and eicosanoid metabolism. (101).

Thus, it is clear that antibiotics can have profound, previously unappreciated effects on human health, and that the effects of the indiscriminate use of antibiotics extend beyond the development of microbial drug resistance (101).

In turn, GM may be an important environmental factor that influences the inter-individual variations in drug efficiency.

\section{DIAGNOSTIC IMPLICATIONS}

A new frontier in medicine is to achieve personalized approaches to monitor, diagnose, and treat the patients according to their genetic and phenotype traits.

Related to this, it is of great interest to individuate samples for a "personalized proteome": the advanced proteome technologies have led to novel opportunities to identify biomarkers based on human microbiome studies and to use them for new clinical diagnostic tests based on these methods. However, it has still to overcome some challenges to reach routine clinical analysis: missing of a worldwide standardization in sample collection, bio-banking, processing, and clinical validation and the high intra- and inter-subject variabilities between samples (102).

To establish causality in the deterioration of the host-microbiota relationship is of great importance; however, discovery of candidate molecules and pathways that underline mechanisms remains a major challenge. Several approaches have been used to achieve an insight into host 
responses to the microbiota, such as transcriptional assays, cytokine panels and imaging analyses, applied to animals.

Furthermore, measuring individual's responses requires tissue samples obtained through invasive procedures, thus leading many difficulties to obtain samples, particularly for the purpose of monitoring patient's response to therapeutic interventions (103).

For this reason, stool is the eligible sample for measuring host responses, as it is acquired noninvasively and contains molecules of both host and microbial origin; these molecules can directly describe the gut ecosystem without confounding with non-gastrointestinal contributions, as is the case in other samples such as blood. Host proteins have a key role in the dynamics of hostmicrobial interactions and are conveniently measured from feces $(103,104)$.

Moreover, stool can provide additional data from previously conducted experiments, as proteins in frozen fecal specimens are available to be further analyzed (103).

Currently, PCR-based assays offer a commercial available test that provides immediate clinical information of gut health. They routinely measure the commensal bacteria in stool, which reveal the composition, diversity, and relative abundance of a key set of clinically relevant genera/species (102).

Also metabolome changes could predict disease, as shown by the data from a pilot study comparing patients bearing colonic diverticula with controls (105). Metabolomics offers a comprehensive qualitative and quantitative overview of the metabolites present in a biological system and could help identifying clinically relevant biomarkers associated with diseases (106).

In conclusion, the combination of microbial community, metabolite, host protein analyses from stool and the use of gnotobiotic animal models, will allow to individuate the proteins that help maintaining balance within this complex ecosystem and those that perturb it.

A multi-dimensional definition of GM state will allow to isolate patients, set up individualized treatment and monitor the disease progression and recovery. 
These approaches also provide a first step to the discovery of diseases-related biomarkers: one or a few proteins that individuate "signatures" in patients and could provide a simple tool for diagnosing a spectrum of gastrointestinal diseases. Such markers may be helpful to understand the disease mechanism and to direct pharmaceutical development (103).

\section{FUTURE PERSPECTIVES}

Due to the great increase of studies raised in the past few years, we have accessed to a deeper knowledge on GM and its relationship to the host, during health and diseases as well as during whole life course.

The great amount of information will allow to detect potential targets for therapeutical strategies and to manipulate the GM through diet (use of functional food), pre- and probiotics intake and administration of antibiotics directed to specific microbial species.

As we know the mechanisms by which the GM contributes to pathologies we could set up an "intelligent modulation" of the GM and to precisely determine its effects on the intestinal community and the host, thus having the possibility to be extremely beneficial for human health $(84,107)$. 


\section{REFERENCES}

1. Peterson CT, Sharma V, Elmén L, Peterson SN. Immune homeostasis, dysbiosis and therapeutic modulation of the gut microbiota. Clin Exp Immunol 2015;179:363-77. doi:10.1111/cei.12474

2. D'Amelio P, Sassi F. Gut Microbiota, Immune System, and Bone. Calcif Tissue Int 2017; [Epub ahead of print]. doi:10.1007/s00223-017-0331-y

3. Davie JR. Inhibition of histone deacetylase activity by butyrate. J Nutr 2003;133:2485S2493S.

4. Tremaroli V, Bäckhed F. Functional interactions between the gut microbiota and host metabolism. Nature 2012;489:242-9. doi:10.1038/nature11552

5. Ferreira CM, Vieira AT, Vinolo MA, Oliveira FA, Curi R, Martins Fdos S. The central role of the gut microbiota in chronic inflammatory diseases. J Immunol Res 2014;2014:689492. doi:10.1155/2014/689492

6. Furusawa Y, Obata Y, Fukuda S, Endo TA, Nakato G, Takahashi D, Nakanishi Y, Uetake C, Kato K, Kato T, Takahashi M, Fukuda NN, Murakami S, Miyauchi E, Hino S, Atarashi K, Onawa S, Fujimura Y, Lockett T, Clarke JM, Topping DL, Tomita M, Hori S, Ohara O, Morita T, Koseki H, Kikuchi J, Honda K, Hase K, Ohno H. Commensal microbe-derived butyrate induces the differentiation of colonic regulatory T cells. Nature 2013;504:446-50. doi:10.1038/nature12721

7. Smith PM, Howitt MR, Panikov N, Michaud M, Gallini CA, Bohlooly-Y M, Glickman JN, Garrett WS. The microbial metabolites, short-chain fatty acids, regulate colonic Treg cell homeostasis. Science 2013;341:569-73. doi:10.1126/science.1241165

8. Liu L, Li L, Min J, Wang J, Wu H, Zeng Y, Chen S, Chu Z. Butyrate interferes with the differentiation and function of human monocyte-derived dendritic cells. Cell Immunol 2012;277:6673. doi:10.1016/j.cellimm.2012.05.011 
9. Millard AL, Mertes PM, Ittelet D, Villard F, Jeannesson P, Bernard J. Butyrate affects differentiation, maturation and function of human monocyte-derived dendritic cells and macrophages. Clin Exp Immunol 2002;130:245-55.

10. Singh N, Thangaraju M, Prasad PD, Martin PM, Lambert NA, Boettger T, Offermanns S, Ganapathy V. Blockade of dendritic cell development by bacterial fermentation products butyrate and propionate through a transporter (Slc5a8)-dependent inhibition of histone deacetylases. J Biol Chem 2010;285:27601-8. doi:10.1074/jbc.M110.102947

11. Wang B, Morinobu A, Horiuchi M, Liu J, Kumagai S. Butyrate inhibits functional differentiation of human monocytederived dendritic cells. Cell Immunol 2008;253:54-8. doi:10.1016/j.cellimm.2008.04.016

12. Singh N, Gurav A, Sivaprakasam S, Brady E, Padia R, Shi H, Thangaraju M, Prasad PD, Manicassamy S, Munn DH, Lee JR, Offermanns S, Ganapathy V. Activation of Gpr109a, receptor for niacin and the commensal metabolite butyrate, suppresses colonic inflammation and carcinogenesis. Immunity 2014;40:128-39. doi:10.1016/j.immuni.2013.12.007

13. Trompette A, Gollwitzer ES, Yadava K, Sichelstiel AK, Sprenger N, Ngom-Bru C, Blanchard C, Junt T, Nicod LP, Harris NL, Marsland BJ. Gut microbiota metabolism of dietary fiber influences allergic airway disease and hematopoiesis. Nat Med 2014;20:159166. doi: $10.1038 / \mathrm{nm} .3444$

14. Postler TS, Ghosh S. Understanding the holobiont: how microbial metabolites affect human health and shape the immune system. Cell Metab 2017;26:110-30. doi:10.1016/j.cmet.2017.05.008

15. Round JL, Lee SM, Li J, Tran G, Jabri B, Chatila TA, Mazmanian SK. The Toll-like receptor 2 pathway establishes colonization by a commensal of the human microbiota. Science 2011;332:974-7. doi:10.1126/science.1206095 
16. Longman RS, Yang Y, Diehl GE, Kim SV, Littman DR. Microbiota: host interactions in mucosal homeostasis and systemic autoimmunity. Cold Spring Harb Symp Quant Biol 2013;78:193-201. doi:10.1101/sqb.2013.78.020081

17. Kostic AD, Howitt MR, Garrett WS. Exploring host-microbiota interactions in animal models and humans. Genes Dev 2013;27:701-18. doi:10.1101/gad.212522.112

18. Sharon G, Segal D, Ringo JM, Hefetz A, Zilber-Rosenberg I, Rosenberg E. Commensal bacteria play a role in mating preference of Drosophila melanogaster. Proc Natl Acad Sci 2010;107:20051-6.

19. Cho I, Yamanishi S, Cox L, Methé BA, Zavadil J, Li K, Gao Z, Mahana D, Raju K, Teitler I, Li H, Alekseyenko AV, Blaser MJ. Antibiotics in early life alter the murine colonic microbiome and adiposity. Nature 2012;488: 621-6.

20. Sjogren K, Engdahl C, Henning P, Lerner UH, Tremaroli V, Lagerquist MK, Ba“ckhed F, Ohlsson C. The gut microbiota regulates bone mass in mice. J Bone Miner Res 2012;27: $1357-67$.

21. Wang Z, Klipfell E, Bennett BJ, Koeth R, Levison BS, Dugar B, Feldstein AE, Britt EB, Fu X, Chung YM, Wu Y, Schauer P, Smith JD, Allayee H, Tang WH, DiDonato JA, Lusis AJ, Hazen SL. Gut flora metabolism of phosphatidylcholine promotes cardiovascular disease. Nature 2011;472:57-63.

22. Semova I, Carten JD, Stombaugh J, Mackey LC, Knight R, Farber SA, Rawls JF. Microbiota regulate intestinal absorption and metabolism of fatty acids in the zebrafish. Cell Host Microbe 2012;12:277-288.

23. Smith K, McCoy KD, Macpherson AJ. Use of axenic animals in studying the adaptation of mammals to their commensal intestinal microbiota. Semin Immunol 2007;19:59-69. doi:10. 1016/j.smim.2006.10.002 
24. Fritz JV, Desai MS, Shah P, Schneider JG, Wilmes P. From meta-omics to causality: experimental models for human microbiome research. Microbiome 2013;1:14. doi:10.1186/2049-2618-1-14

25. Trexler PC, Hon D, Orcutt RP. Development of Gnotobiotics and contamination control in laboratory animal science introduction: nomenclature. 50 Years of Laboratory Animal Science. American association for laboratory animal science, American Association for Laboratory Animal Science( Memphis, TN) 1999; Book Chapter 16:121-8. http://www.aalas.org/association/about.aspx

26. Spor A, Koren O, Ley R.. Unravelling the effects of the environment and host genotype on the gut microbiome. Nat Rev Microbiol 2011;9:279-290.

27. Chung H, Pamp SJ, Hill J, Surana NK, Edelman SM, Troy EB, Reading NC, Villablanca EJ, Wang S, Mora JR, Umesaki Y, Mathis D, Benoist C, Relman D, Kasper DL: Gut immune maturation depends on colonization with a host-specific microbiota. Cell 2012;149:157893.

28. Mestas J, Hughes CCW. Of mice and not men: differences between mouse and human immunology. J Immunol 2004;172:2731-8.

29. Legrand N, Ploss A, Balling R, Becker PD, Borsotti C, Brezillon N, Debarry J, De Jong Y, Deng H, Di Santo JP, Eisenbarth S, Eynon E, Flavell R, Guzman C, Huntington ND, Kremsdorf D, Manns MP, Manz MG, Mention JJ, Ott M, Rathinam C, Rice CM, Rongvaux A, Stevens S, Spits H, Strick-Marchand H, Takizawa H, Van Lent AU, Wang C, Weijer K, Willinger T, Ziegler P. Humanized mice for modeling human infectious disease: challenges, progress, and outlook. Cell Host Microbe 2009;6:5-9.

30. Belkaid Y, Hand TW. Role of the microbiota in immunity and inflammation. Cell 2014;157:121-41. doi:10.1016/j.cell.2014.03.011

31. Wu HJ, Wu E. The role of gut microbiota in immune homeostasis and autoimmunity. Gut Microbes 2012;3:4-14. doi:10.4161/gmic.19320 
32. Bauer H, Horowitz RE, Levenson SM, Popper H. The response of the lymphatic tissue to the microbial flora. Studies on germfree mice. Am J Pathol 1963;42:471-83.

33. Hamada H, Hiroi T, Nishiyama Y, Takahashi H, Masunaga Y, Hachimura S, Kaminogawa S, Takahashi-Iwanaga H, Iwanaga T, Kiyono H, Yamamoto H, Ishikawa H. Identification of multiple isolated lymphoid follicles on the antimesenteric wall of the mouse small intestine. J Immunol 2002;168:57-64.

34. Macpherson AJ, Hunziker L, McCoy K, Lamarre A. IgA responses in the intestinal mucosa against pathogenic and nonpathogenic microorganisms. Microbes Infect 2001;3:1021-35.

35. Mazmanian SK, Liu CH, Tzianabos AO, Kasper DL. An immunomodulatory molecule of symbiotic bacteria directs maturation of the host immune system. Cell 2005;122:107-118. doi:10.1016/j.cell.2005.05.007

36. Talham GL, Jiang HQ, Bos NA, Cebra JJ. Segmented filamentous bacteria are potent stimuli of a physiologically normal state of the murine gut mucosal immune system. Infect Immun 1999;67:1992-2000.

37. Bouskra D1, Brézillon C, Bérard M, Werts C, Varona R, Boneca IG, Eberl G. Lymphoid tissue genesis induced by commensals through NOD1 regulates intestinal homeostasis. Nature 2008;456:507-10. doi:10.1038/nature07450

38. Ohnmacht C, Marques R, Presley L, Sawa S, Lochner M, Eberl G. Intestinal microbiota, evolution of the immune system and the bad reputation of pro-inflammatory immunity. Cell Microbiol 2011;13:653-9. doi:10.1111/j.1462-5822.2011.01577.x

39. Lee N, Kim WU. Microbiota in T-cell homeostasis and inflammatory diseases. Exp Mol Med 2017;49:e340. doi:10.1038/emm.2017.36

40. Atarashi K, Tanoue T, Shima T, Imaoka A, Kuwahara T, Momose Y, Cheng G, Yamasaki S, Saito T, Ohba Y, Taniguchi T, Takeda K, Hori S, Ivanov II, Umesaki Y, Itoh K, Honda K. 
Induction of colonic regulatory $\mathrm{T}$ cells by indigenous Clostridium species. Science 2011;331:337-41. doi:10.1126/science.1198469

41. Gaboriau-Routhiau V, Rakotobe S, Lécuyer E, Mulder I, Lan A, Bridonneau C, Rochet V, Pisi A, De Paepe M, Brandi G, Eberl G, Snel J, Kelly D, Cerf-Bensussan N. The key role of segmented filamentous bacteria in the coordinated maturation of gut helper $\mathrm{T}$ cell responses. Immunity 2009;31:677-89. doi:10.1016/j.immuni.2009.08.020

42. Lane ER, Zisman TL, Suskind DL. The microbiota in inflammatory bowel disease: current and therapeutic insights. J Inflamm Res 2017;10:63-73. doi:10.2147/JIR.S116088

43. Maeda Y, Takeda K. Role of gut microbiota in rheumatoid arthritis. J Clin Med 2017;6:60. doi: $10.3390 /$ jcm6060060

44. Wen L, Ley RE, Volchkov PY, Stranges PB, Avanesyan L, Stonebraker AC, Hu C, Wong FS, Szot GL, Bluestone JA, Gordon JI, Chervonsky AV. Innate immunity and intestinal microbiota in the development of Type 1 diabetes. Nature 2008;455:1109-13. doi:10.1038/nature07336

45. Shukla SD, Budden KF, Neal R, Hansbro PM. Microbiome effects on immunity, health and disease in the lung. Clin Transl Immunol 2017;6:e133. doi:10.1038/cti.2017.6

46. Schroeder BO, Bäckhed F. Signals from the gut microbiota to distant organs in physiology and disease. Nat Med 2016;22:1079-89. doi:10.1038/nm.4185

47. Hernlund E, Svedbom A, Ivergård M, Compston J, Cooper C, Stenmark J, McCloskey EV, Jönsson B, Kanis JA. Osteoporosis in the European Union: medical management, epidemiology and economic burden. A report prepared in collaboration with the

International Osteoporosis Foundation (IOF) and the European Federation of Pharmaceutical Industry Associations (EFPIA). Arch Osteoporos 2013;8:136. doi:10.1007/s11657-013-0136-1

48. Mori G, D’Amelio P, Faccio R, Brunetti G. Bone-immune cell crosstalk: bone diseases. J Immunol Res 2015;2015:108451. doi:10.1155/2015/108451 
49. D’Amelio P, Grimaldi A, Di Bella S, Brianza SZ, Cristofaro MA, Tamone C, Giribaldi G, Ulliers D, Pescarmona GP, Isaia G. Estrogen deficiency increases osteoclastogenesis upregulating T cells activity: a key mechanism in osteoporosis. Bone 2008;43:92-100. doi:10.1016/j.bone.2008.02.017

50. Yan J, Herzog JW, Tsang K, Brennan CA, Bower MA, Garrett WS, Sartor BR, Aliprantis AO, Charles JF. Gut microbiota induce IGF-1 and promote bone formation and growth. Proc Natl Acad Sci USA 2016;113:E7554-63. doi:10.1073/pnas.1607235113

51. Cox LM, Yamanishi S, Sohn J, Alekseyenko AV, Leung JM, Cho I, Kim SG, Li H, Gao Z, Mahana D, Zárate Rodriguez JG, Rogers AB, Robine N, Loke P, Blaser MJ. Altering the intestinal microbiota during a critical developmental window has lasting metabolic consequences. Cell 2014;158:705-21. doi:10.1016/j.cell.2014.05.052

52. Nobel YR, Cox LM, Kirigin FF, Bokulich NA, Yamanishi S, Teitler I, Chung J, Sohn J, Barber CM, Goldfarb DS, Raju K, Abubucker S, Zhou Y, Ruiz VE, Li H, Mitreva M, Alekseyenko AV, Weinstock GM, Sodergren E, Blaser MJ. Metabolic and metagenomic outcomes from early-life pulsed antibiotic treatment. Nat Commun 2015;6:7486. doi:10.1038/ncomms 8486

53. Pytlik M, Folwarczna J, Janiec W. Effects of doxycycline on mechanical properties of bones in rats with ovariectomyinduced osteopenia. Calcif Tissue Int 2004;75:225-30. doi:10.1007/s00223-004-0097-x

54. Guss JD, Horsfield MW, Fontenele FF, Sandoval TN, Luna M, Apoorva F, Lima SF, Bicalho RC, Singh A, Ley RE, van der Meulen MC, Goldring SR, Hernandez CJ. Alterations to the gut microbiome impair bone strength and tissue material properties. $\mathrm{J}$ Bone Miner Res 2017;32:1343-53. doi:10.1002/jbmr.3114

55. Li JY, Chassaing B, Tyagi AM, Vaccaro C, Luo T, Adams J, Darby TM, Weitzmann MN, Mulle JG, Gewirtz AT, Jones RM, Pacifici R. Sex steroid deficiency-associated bone loss is 
microbiota dependent and prevented by probiotics. J Clin Invest 2016;126:2049-63. doi:10.1172/JCI86062

56. Zeissig S, Bürgel N, Günzel D, Richter J, Mankertz J, Wahnschaffe U, Kroesen AJ, Zeitz M, Fromm M, Schulzke JD. Changes in expression and distribution of claudin 2, 5 and 8 lead to discontinuous tight junctions and barrier dysfunction in active Crohn's disease. Gut 2007;56:61-72. doi:10.1136/gut.2006.094375

57. Grootjans J, Thuijls G, Verdam F, Derikx JP, Lenaerts K, Buurman WA. Non-invasive assessment of barrier integrity and function of the human gut. World J Gastrointest Surg 2010;2:61-9. doi:10.4240/wjgs.v2.i3.61

58. Wang J, Wang Y, Gao W, Wang B, Zhao H, Zeng Y, Ji Y, Hao D. Diversity analysis of gut microbiota in osteoporosis and osteopenia patients. Peer J 2017;5:e3450. doi:10.7717/peerj.3450

59. Jones ML, Martoni CJ, Prakash S. Oral supplementation with probiotic L. reuteri NCIMB 30242 increases mean circulating 25-hydroxyvitamin D: a post hoc analysis of a randomized controlled trial. J Clin Endocrinol Metab 2013;98:2944-51. doi:10.1210/jc.2012-4262

60. Yoon SS, Sun J. Probiotics, nuclear receptor signaling, and anti-inflammatory pathways. Gastroenterol Res Pract 2011;2011:971938. doi:10.1155/2011/971938

61. Ly NP, Litonjua A, Gold DR, Celedòn JC. Gut microbiota, probiotics, and vitamin D: interrelated exposures influencing allergy, asthma, and obesity? J Allergy Clin Immunol 2011;127:1087-94. doi:10.1016/j.jaci.2011.02.015

62. Weaver CM, Gordon CM, Janz KF, Kalkwarf HJ, Lappe JM, Lewis R, O'Karma M, Wallace TC, Zemel BS. The National Osteoporosis Foundation's position statement on peak bone mass development and lifestyle factors: a systematic review and implementation recommendations. Osteoporos Int 2016;27:1281-1386. doi:10.1007/s00198-015-3440-3

63. D’Amelio P, Tamone C, Pluviano F, Di Stefano M, Isaia G. Effects of lifestyle and risk factors on bone mineral density in a cohort of Italian women: suggestion for a new 
decision rule. Calcif Tissue Int 2005;77:72-8. doi:10.1007/s00223-004-0253-3

64. Wallace TC, Marzorati M, Spence L, Weaver CM, Williamson PS. New frontiers in fibers: innovative and emerging research on the gut microbiome and bone health. J Am Coll Nutr 2017;36:218-22. doi:10.1080/07315724.2016.1257961

65. Weaver CM. Diet, gut microbiome, and bone health. Curr Osteoporos Rep 2015;13:125-30. doi:10.1007/s11914-015-0257-0

66. U.S. Department of Health and Human Services and U.S. Departmentof Agriculture. 20152020 Dietary Guidelines for Americans, 8th edn. (Washington, DC), 2015. http://health.gov/dietaryguidelines/2015/guidelines

67. D'Amelio P, Panico A, Spertino E, Isaia GC. Energy metabolism and the skeleton: reciprocal interplay. World J Orthop 2012;3:190-8. doi:10.5312/wjo.v3.i11.190

68. Reigstad CS, Salmonson CE, Rainey JF 3rd, Szurszewski JH, Linden DR, Sonnenburg JL, Farrugia G, Kashyap PC. Gut microbes promote colonic serotonin production through an effect of short-chain fatty acids on enterochromaffin cells. FASEB J 2015;29:1395-1403. doi:10.1096/fj.14-259598

69. Yano JM, Yu K, Donaldson GP, Shastri GG, Ann P, Ma L, Nagler CR, Ismagilov RF, Mazmanian SK, Hsiao EY. Indigenous bacteria from the gut microbiota regulate host serotonin biosynthesis. Cell 2015;161:264-76. doi:10.1016/j.cell.2015.02.047

70. Yadav VK, Balaji S, Suresh PS, Liu XS, Lu X, Li Z, Guo XE, Mann JJ, Balapure AK, Gershon MD, Medhamurthy R, Vidal M, Karsenty G, Ducy P. Pharmacological inhibition of gut-derived serotonin synthesis is a potential bone anabolic treatment for osteoporosis. Nat Med 2010;16:308-12. doi:10.1038/nm.2098

71. Gibson GR, Roberfroid MB. Dietary modulation of the human colonic microbiota: introducing the concept of prebiotics. J Nutr 1995;125:1401-12.

72. Roberfroid M. Prebiotics: the concept revisited. J Nutr 2007;137:830S-7S 
73. Li D, Wang P, Wang P, Hu X, Chen F. The gut microbiota: A treasure for human health. Biotechnol Adv 2016;34:1210-24. doi:10.1016/j.biotechadv.2016.08.003

74. Walker AW, Ince J, Duncan SH, Webster LM, Holtrop G, Ze X, Brown D, Stares MD, Scott P, Bergerat A, Louis P, McIntosh F, Johnstone AM, Lobley GE, Parkhill J, Flint HJ. Dominant and diet-responsive groups of bacteria within the human colonic microbiota. ISME J 2011;5:220-30.

75. Scott KP, Martin JC, Chassard C, Clerget M, Potrykus J, Campbell G, Mayer CD, Young P, Rucklidge G, Ramsay AG, Flint HJ. Substrate-driven gene expression in Roseburia inulinivorans: importance of inducible enzymes in the utilization of inulin and starch. Proc Natl Acad Sci U S A. 2011;108:4672-9. doi:10.1073/pnas.1000091107

76. Walton GE, van den Heuvel EG, Kosters MH, Rastall RA, Tuohy KM, Gibson GR. A randomised crossover study investigating the effects of galacto-oligosaccharides on the faecal microbiota in men and women over 50 years of age. Br J Nutr 2012;107:1466-75.

77. Cani PD, Possemiers S, Van deWiele T, Guiot Y, Everard A, Rottier O, Geurts L, Naslain D, Neyrinck A, Lambert DM, Muccioli GG, Delzenne NM. Changes in gut microbiota control inflammation in obese mice through a mechanism involving GLP-2-driven improvement of gut permeability. Gut 2009;58:1091-1103. doi:10.1136/gut.2008.165886

78. Weaver CM, Martin BR, Nakatsu CH, Armstrong AP, Clavijo A, McCabe LD, McCabe GP, Duignan S, Schoterman MH, van den Heuvel EG. Galactooligosaccharides improve mineral absorption and bone properties in growing rats through gut fermentation. J Agric Food Chem 2011;59:6501-10. doi:10.1021/jf2009777

79. Scholz-Ahrens KE, Schaafsma G, van den Heuvel EG, Schrezenmeir J. Effects of prebiotics on mineral metabolism. Am J ClinNutr 2001;73:459S-464S.

80. Whisner CM, Martin BR, Schoterman MH, Nakatsu CH, McCabe LD, McCabe GP, Wastney ME, van den Heuvel EG, Weaver CM. Galacto-oligosaccharides increase calcium absorption and gut Bifidobacteria in young girls: a double-blind cross-over trial. Br J 
Nutr 2013;110:1292-1303. doi:10.1017/S000711451300055X

81. Abrams SA, Griffin IJ, Hawthorne KM, Liang L, Gunn SK, Darlington G, Ellis KJ. A combination of prebiotic short- and long-chain inulin-type fructans enhances calcium absorption and bone mineralization in young adolescents. Am J Clin Nutr 2005;82:471-6

82. Whisner CM, Martin BR, Nakatsu CH, Story JA, MacDonald-Clarke CJ, McCabe LD, McCabe GP, Weaver CM. Soluble corn fiber increases calcium absorption associated with shifts in the gut microbiome: a randomized dose-response trial in free-living pubertal females. J Nutr 2016;146:1298-1306. doi:10.3945/jn.115.227256

83. Whisner CM, Martin BR, Nakatsu CH, McCabe GP, McCabe LD, Peacock M, Weaver CM. Soluble maize fibre affects short-term calcium absorption in adolescent boys and girls: a randomised controlled trial using dual stable isotopic tracers. Br J Nutr 2014;112:446-56. doi:10.1017/S0007114514000981

84. Bindels LB, Delzenne NM, Cani PD, Walter J. Towards a more comprehensive concept for prebiotics. Nat Rev Gastroenterol Hepatol 2015;12:303-10. doi:10.1038/nrgastro.2015.47

85. Araya MML, Reid G, Sanders ME, Stanton C. Guidelines for the Evaluation of Probiotics in Food, Jt. 2002; FAO/WHO Work Group, London, Ontario.

86. Ohlsson C, Engdahl C, Fåk F, Andersson A, Windahl SH, Farman HH, Movérare-Skrtic S, Islander U, Sjögren K. Probiotics protect mice from ovariectomy-induced cortical bone loss. PLoS ONE 2014;9:e92368. doi:10.1371/journal.pone.0092368

87. Britton RA, Irwin R, Quach D, Schaefer L, Zhang J, Lee T, Parameswaran N, McCabe LR. Probiotic L. reuteri treatment prevents bone loss in a menopausal ovariectomized mouse model. J Cell Physiol 2014;229:1822-30. doi:10.1002/jcp.24636

88. Parvaneh K, Ebrahimi M, Sabran MR, Karimi G, Hwei AN, Abdul-Majeed S, Ahmad Z, Ibrahim Z, Jamaluddin R. Probiotics (Bifidobacterium longum) increase bone mass density and upregulate SPARC and BMP-2 genes in rats with bone loss resulting from ovariectomy. Biomed Res Int 2015;2015:897639. doi:10.1155/2015/897639 
89. Rozenberg S, Body JJ, Bruyère O, Bergmann P, Brandi ML, Cooper C, Devogelaer JP, Gielen E, Goemaere S, Kaufman JM, Rizzoli R, Reginster JY. Effects of dairy products consumption on health: benefits and beliefs-a commentary from the Belgian bone club and the European society for clinical and economic aspects of osteoporosis, osteoarthritis and musculoskeletal diseases. Calcif Tissue Int 2016;98:1-17. doi:10.1007/s00223-015-0062-x

90. Matkovic V, Landoll JD, Badenhop-Stevens NE, Ha EY, Crncevic-Orlic Z, Li B, Goel P. Nutrition influences skeletal development from childhood to adulthood: a study of hip, spine, and forearm in adolescent females. J Nutr 2004;134:701s-05s

91. Langsetmo L, Barr SI, Berger C, Kreiger N, Rahme E, Adachi JD, Papaioannou A, Kaiser SM, Prior JC, Hanley DA, Kovacs CS, Josse RG, Goltzman D; CaMos Research Group. Associations of protein intake and protein source with bone mineral density and fracture risk: a population-based cohort study. J Nutr Health Aging 2015;19:861-8. doi:10.1007/s12603-015-0544-6

92. Durosier-Izart C, Biver E, Merminod F, van Rietbergen B, Chevalley T, Herrmann FR, Ferrari SL, Rizzoli R. Peripheral skeleton bone strength is positively correlated with total and dairy protein intakes in healthy postmenopausal women. Am J Clin Nutr 2017;105:51325. doi:10.3945/ajen.116.134676

93. Radavelli-Bagatini S, Zhu K, Lewis JR, Prince RL. Dairy food intake, peripheral bone structure, and muscle mass in elderly ambulatory women. J Bone Miner Res 2014;29:16911700. doi:10.1002/jbmr.2181

94. Laird E, Molloy AM, McNulty H, Ward M, McCarroll K, Hoey L, Hughes CF, Cunningham C, Strain JJ, Casey MC. Greater yogurt consumption is associated with increased bone mineral density and physical function in older adults. Osteoporos Int 2017;28:2409-19. doi:10.1007/s00198-017-4049-5 
95. Pazzini CA, Pereira LJ, da Silva TA, Montalvany-Antonucci CC, Macari S, Marques LS, de Paiva SM. Probiotic consumption decreases the number of osteoclasts during orthodontic movement in mice. Arch Oral Biol 2017;79:30-4. doi:10.1016/j.archoralbio.2017.02.017

96. Ricoldi MST, Furlaneto FAC, Oliveira LFF, Teixeira GC, Pischiotini JP, Moreira ALG, Ervolino E, de Oliveira MN, Bogsan CSB, Salvador SL, Messora MR. Effects of the probiotic Bifidobacterium animalis subsp. lactis on the non-surgical treatment of periodontitis. A histomorphometric, microtomographic and immunohistochemical study in rats. PLoS ONE 2017;12:e0179946. doi:10.1371/journal.pone.0179946

97. Kobayashi R, Kobayashi T, Sakai F, Hosoya T, Yamamoto M, Kurita-Ochiai T. Oral administration of Lactobacillus gasseri SBT2055 is effective in preventing Porphyromonas gingivalis-accelerated periodontal disease. Sci Rep 2017;7:545. doi:10.1038/s41598-01700623-9

98. Gruner D, Paris S, Schwendicke F. Probiotics for managing caries and periodontitis: systematic review and metaanalysis. J Dent 2016;48:16-25. doi:10.1016/j.jdent.2016.03.002 99. Gohel MK, Prajapati JB, Mudgal SV, Pandya HV, Singh US, Trivedi SS, Phatak AG, Patel RM. Effect of probiotic dietary intervention on calcium and haematological parameters in geriatrics. J Clin Diagn Res 2016;10:5-9. doi:10.7860/JCDR/2016/18877.7627

100. Jafarnejad S, Djafarian K, Fazeli MR, Yekaninejad MS, Rostamian A, Keshavarz SA. Effects of a multispecies probiotic supplement on bone health in osteopenic postmenopausal women: a randomized, double-blind, controlled trial. J Am Coll Nutr 2017;19:1-10. doi:10.1080/07315724.2017.1318724

101. Antunes LC, Han J, Ferreira RB, Lolić P, Borchers CH, Finlay BB. Effect of antibiotic treatment on the intestinal metabolome. Antimicrob Agents Chemother 2011;55:1494-503. doi:10.1128/AAC.01664-10

102. Haange SB, Jehmlich N. Proteomic interrogation of the gut microbiota: potential clinical impact. Expert Rev Proteomics 2016;13:535-7. doi:10.1080/14789450.2016.1190652 
103. Lichtman JS, Sonnenburg JL, Elias JE. Monitoring host responses to the gut microbiota. ISME J 2015;9:1908-15. doi:10.1038/ismej.2015.93

104. Vaishnava S, Yamamoto M, Severson KM, Ruhn KA, Yu X, Koren O, Ley R, Wakeland EK, Hooper LV. The antibacterial lectin RegIIIgamma promotes the spatial segregation of microbiota and host in the intestine. Science 2011;334:255-8.

105. Barbara G, Scaioli E, Barbaro MR, Biagi E, Laghi L, Cremon C, Marasco G, Colecchia A, Picone G, Salfi N, Capozzi F, Brigidi P, Festi D. Gut microbiota, metabolome and immune signatures in patients with uncomplicated diverticular disease. Gut 2017;66:1252-61. doi:10.1136/gutjnl-2016-312377

106. Picone G, Laghi L, Gardini F, Lanciotti R, Siroli L, Capozzi F. Evaluation of the effect of carvacrol on the Escherichia coli 555 metabolome by using 1H-NMR spectroscopy. Food Chem 2013;141:4367-74.

107. Walsh CJ, Guinane CM, O'Toole PW, Cotter PD. Beneficial modulation of the gut microbiota. FEBS Lett 2014;588:4120-30. doi:10.1016/j.febslet.2014.03.035 


\section{LIST OF ACRONYMS AND ABBREVIATIONS}

GM: gut microbiota

NCDs: non-communicable human diseases

SCFAs: short-chaim fatty acids

Tregs: T regulatory cells

Th: T helper cells

GF: germ free

PMO: postmenopausal osteoporosis

5HT/g5HT: serotonin/gut-derived serotonin

FOS: fructooligosaccharides

GOS: galactooligosaccharides

SCF: soluble corn fiber 


\section{FIGURE LEGENDS}

Figure 1. The cartoon shows gut microbiota metabolites and their effects on bone cells.

Abbreviations used: short-chain fatty acids (SCFAs); enteral cells (EC); goblet cells (GC); antigen presenting cells (APC); macrophages (MØ); T regulatory cells (Treg). 


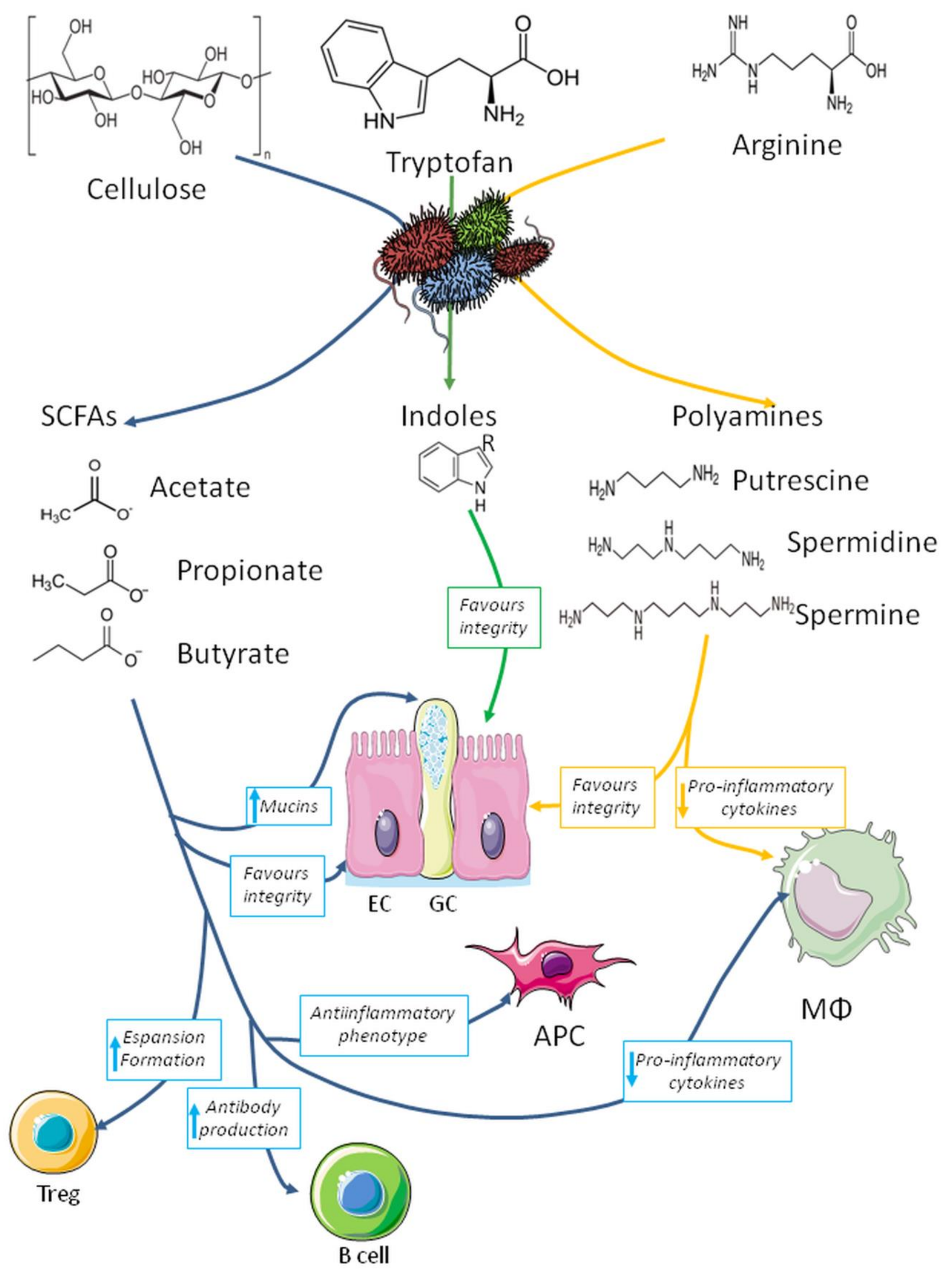


Figure 2. The cartoon shows the relationships between immune system, estrogen deficiency-bone loss and gut microbiota: enteral barrier integrity, cytokine production, immune and bone cells are involved.

Abbreviations used: gut microbiota (GM); enteral cells (EC); antigen presenting cells (APC); T regulatory cells (Treg); T helper-1 cells (Th1); T helper-17 cells (Th17); osteoclasts (OCs).

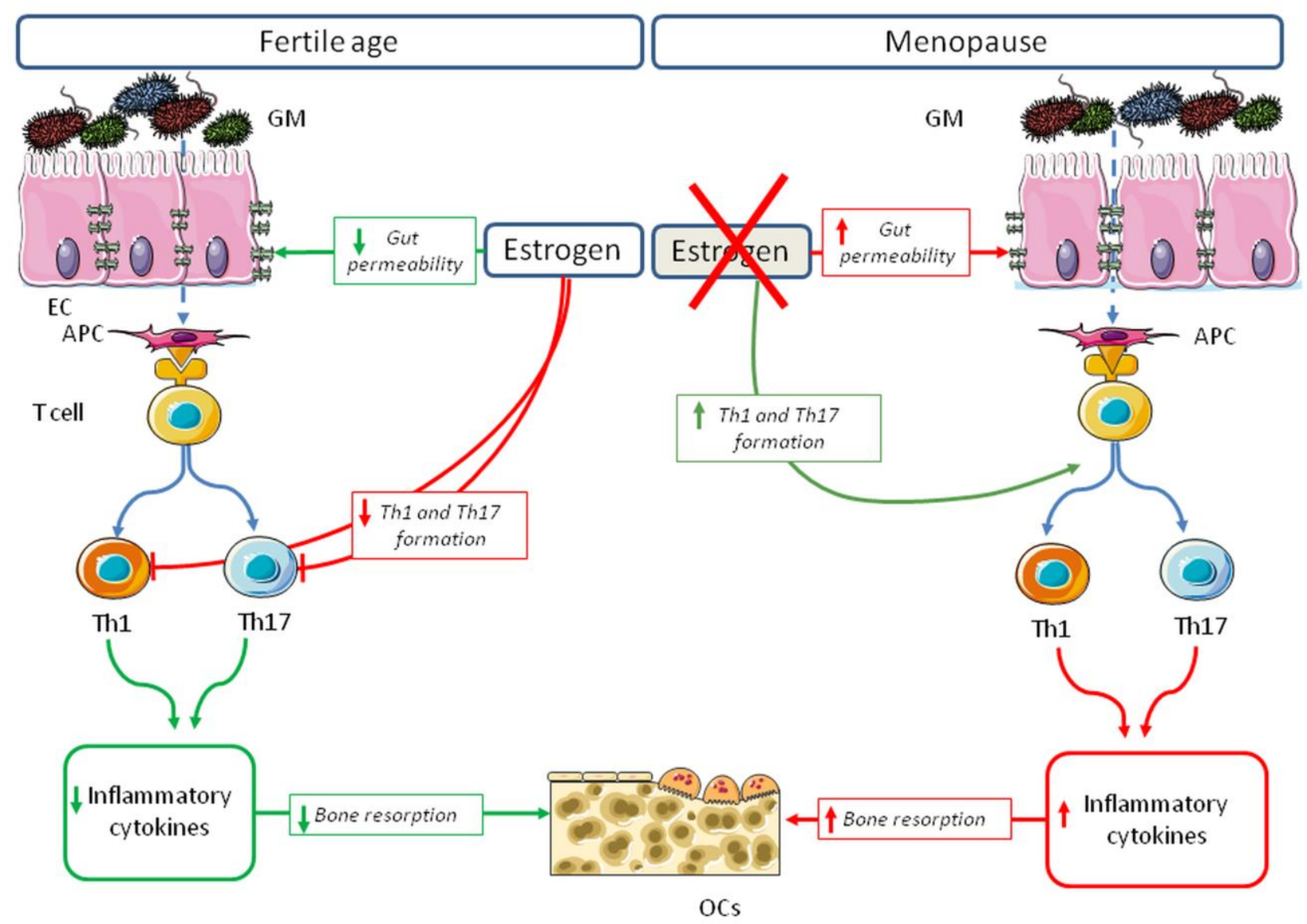

Figure 3. The cartoon shows the link between gut microbiota and bone turnover beyond immune system.

Abbreviations used: gut microbiota (GM), enteral cells (EC), enterochromaffin cells (ECC), goblet cells (GC); osteoblasts (OBs). 


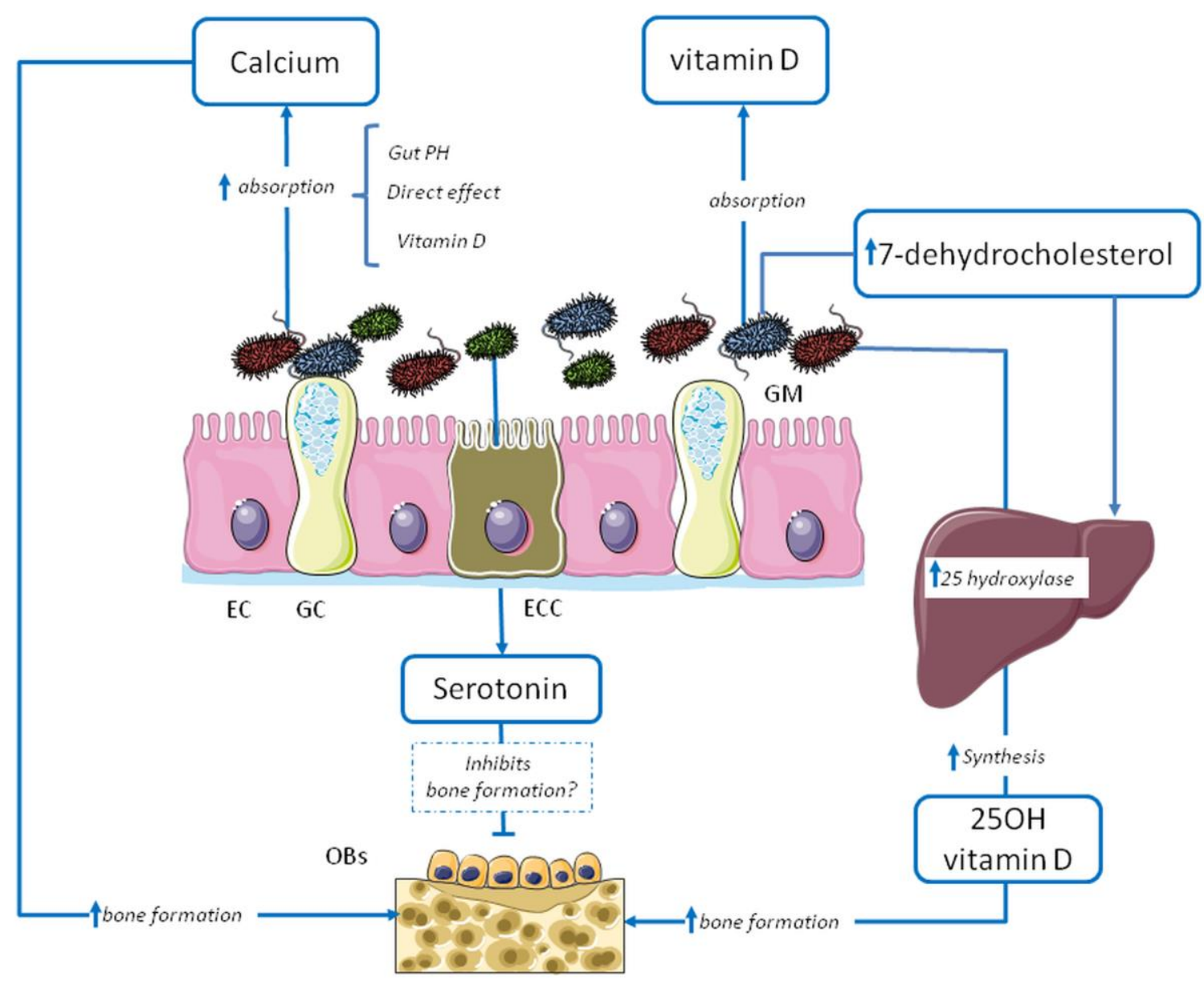


Table 1.

\begin{tabular}{|c|c|c|c|c|c|}
\hline Subjects recruited & $\begin{array}{l}\text { Number of } \\
\text { subjects }\end{array}$ & Pre-biotic used & $\begin{array}{l}\text { Dose and } \\
\text { time }\end{array}$ & Out-comes & Reference \\
\hline Adolescents & $\begin{array}{l}50 \text { males } \\
50 \text { females }\end{array}$ & $\begin{array}{l}\text { Oligofructanes, } \\
\text { long-chain inuline }\end{array}$ & $\begin{array}{c}8 \mathrm{~g} / \mathrm{die} \\
12 \text { months }\end{array}$ & $\begin{array}{c}\uparrow C \text { Ca absorption } \\
\uparrow \text { Bone mineral } \\
\text { density }\end{array}$ & 81 \\
\hline Preadolescent & 31 females & Galattoligosaccarides & $\begin{array}{l}5-10 \mathrm{~g} / \mathrm{die} \\
3 \text { weeks }\end{array}$ & $\uparrow \mathrm{Ca}$ absorption & 80 \\
\hline Adolescents & $\begin{array}{l}15 \text { males } \\
9 \text { females }\end{array}$ & Soluble corn fiber & $\begin{array}{l}12 \mathrm{~g} / \mathrm{die} \\
3 \text { weeks }\end{array}$ & $\begin{array}{c}\uparrow \mathrm{Ca} \text { absorption } \\
\uparrow \text { Bacteroides }\end{array}$ & 83 \\
\hline Adolescent & 28 females & Soluble corn fiber & $\begin{array}{l}10-20 \mathrm{~g} / \mathrm{die} \\
4 \text { weeks }\end{array}$ & $\begin{array}{c}\uparrow \text { Ca absorption } \\
\text { and bone } \\
\text { markers } \\
\uparrow \text { Bacteroidetes, } \\
\text { Firmicutes }\end{array}$ & 82 \\
\hline
\end{tabular}

